\title{
A causal loop? The Commission's new enforcement approach in the context of non-compliance with EU law even after CJEU judgments
}

\section{Gerda Falkner}

To cite this article: Gerda Falkner (2018) A causal loop? The Commission's new enforcement approach in the context of non-compliance with EU law even after CJEU judgments, Journal of European Integration, 40:6, 769-784, DOI: 10.1080/07036337.2018.1500565

To link to this article: https://doi.org/10.1080/07036337.2018.1500565
(2) 2018 The Author(s). Published by Informa
UK Limited, trading as Taylor \& Francis Group.

\section{Published online: 12 Dec 2018.}

Submit your article to this journal

Ш Article views: 194

View Crossmark data $\nearrow$

Citing articles: 1 View citing articles 


\title{
A causal loop? The Commission's new enforcement approach in the context of non-compliance with EU law even after CJEU judgments
}

\author{
Gerda Falkner
}

Institute for European Integration Research, University of Vienna, Vienna, Austria

\begin{abstract}
How policy stakeholders receive CJEU rulings will influence the European Commission's reasoning on how much litigation makes sense in order to fight infringements of EU law. Therefore, the article focuses not only on the European Commission but later also on the member states. In the first part, recent data indicate both a limited capacity and new strategy of the Commission for suing non-compliance. The article's later parts analyse the post-proceedings phase in the enforcement of EU law. Fresh data regarding the tip of the iceberg of non-compliance is presented regarding the CJEU's ' 2 nd judgments' (Article 260.2 TFEU). Why do governments risk fines? How awkward do the related quarrels with the Commission get? The conclusions speculate that there might be a negative feedback loop between the great cost but only conditional success of enforcement, on the one hand, and the Commission's propensity to litigate, on the other.
\end{abstract}

\section{KEYWORDS}

Court of Justice of the EU (CJEU); infringement proceedings; fines; Article 260 (2) TFEU; European Commission; member states

\section{Introduction}

This Special Issue explores how the CJEU's possibility to intervene and the effectiveness of its rulings are determined by its policy environment. In that respect the European Commission is a crucial actor as it oversees the application of EU law and decides if and when it takes non-compliance by a member state to Court. A number of recent developments and puzzling facts shall be presented in the first part of this article, hinting at a limited capacity and increased restraint of the European Commission in suing noncompliance (see section 2). To understand why the Commission as a stakeholder in the field of norm enforcement uses the CJEU selectively, it needs mentioning that a Court-based strategy to enforce EU law, albeit the harshest means at hand in the absence of direct enforcement capacities, still lacks unconditional remedial effect.

A public policy approach to the power of the CJEU, as advocated by this Special Issue, presumes that the Court's impact depends on stakeholders and governance structures, including on the policy-specific level (Mathieu et al. 2018, this issue). Next to other factors, this includes actors' conditional propensity to litigate. My contribution highlights how much the first and second parts of this Special Issue are linked. How policy

CONTACT Gerda Falkner gerda.falkner@univie.ac.at $\Theta$ Institute for European Integration Research, University of Vienna, Apostelgasse 23, 1030 Vienna, Austria

(c) 2018 The Author(s). Published by Informa UK Limited, trading as Taylor \& Francis Group.

This is an Open Access article distributed under the terms of the Creative Commons Attribution License (http://creativecommons.org/licenses/ by/4.0/), which permits unrestricted use, distribution, and reproduction in any medium, provided the original work is properly cited. 
stakeholders (in the case of infringement proceedings, primarily the member states) receive CJEU rulings will impact the European Commission's reasoning on how much litigation to fight infringements of EU law makes sense - although it may never publicly admit that. Therefore, my article has two interconnected parts: I focus not only on the European Commission but later also on the member states. I argue that the decline in the initiation of infringement proceedings is probably not only related to shrinking resources as well as to an outsourcing of enforcement to private litigants and national courts (see also Hofmann 2018a, p. 737-751 this issue). It should also be read in the context of mounting doubts if, or how much and at what price, infringements can at all be stopped against the will of the relevant government.

The latter part of the article will hence discuss those cases where member states continuously fail to comply even in the aftermath of CJEU judgments. What explains such misdemeanour? Do governments in such outstanding cases fight for matters of principle, or are they seeking advantages in terms of money or votes? Sections 3 and 4 below will discuss these matters based on latest data and a qualitative content analysis of all ' 2 nd CJEU judgments' (i.e., those under Article 260.2 TFEU). Section 5 will summarise the findings and link them to theories of enforcement.

\section{Infringement proceedings and the puzzle of dwindling court referrals}

Ensuring compliance with EU policies throughout the multi-levelled system is by no means a petty task since the responsibility to implement EU rules rests with the member states, in principle.

Controlling and enforcing EU policies is the European Commission's assignment. ${ }^{1}$ According to Article 17 of the Treaty on European Union (TEU), the Commission 'shall ensure the application of the Treaties, and of measures adopted by the institutions pursuant to them. It shall oversee the application of Union law under the control of the Court of Justice of the European Union.' More specifically, the enforcement of EU law is prescribed in the Treaty on the Functioning of the European Union (TFEU). Its Article 258 outlines that 'if the Commission considers that a member state has failed to fulfil an obligation under the Treaties, it shall deliver a reasoned opinion on the matter after giving the State concerned the opportunity to submit its observations. If the State concerned does not comply with the opinion within the period laid down by the Commission, the latter may bring the matter before the Court of Justice of the European Union.' These are the so-called infringement proceedings which are at the core of the control over compliance with EU policies. $^{2}$

We know that there is a non-trivial degree of non-compliance with EU policies. The true extent is unknown since empirical studies in all member states of how specific provisions are transposed, let alone practically applied, are intrinsically complex and exceedingly costly, and hence cannot possibly cover the full breadth of EU policies. Recent research indicates that even the somewhat less demanding 'ex-post legislative evaluations' by the Commission from 2000 to 2012 covered only about one third of major EU legislation and that lacking evaluation capacity of the relevant Commission Directorate General is a relevant factor (Voorst and Mastenbroek 2017). Interviews revealed 'much variation in the extent to which Directorates-General prioritize evaluation as well as in the amount of human and technological capital 
that they invest in evaluation' which can in part be explained by their total budgets (Voorst 2017: 24).

In individual case studies or sector studies, quite an impressive extent of late or even noncompliance has been found. One of the rare in-depth qualitative studies with a comparatively large number of cases studied 6 social policy Directives in then all 15 member states. It revealed a level of only $11 \%$ good compliance (i.e. action that is both correct and timely) already at the first stage of transposition into national law, still neglecting the without doubt even larger problems with the application of such EU standards (Falkner et al. 2005: 266). To be sure, we need to consider that the amount of non-compliance with laws of national origin is also known to be higher than usually expected and hardly ever studied on a general level, beyond singular legislative projects. In any case, the scale of the compliance gap has been found 'worrying' (Toshkov, Knoll, and Wewerka 2010: 5) by many researchers. Moreover, it seems to affect many kinds of EU-related rules and policies, including quite visible ones such as most recently the issue of helping the member states with relevant external borders via refugee resettlements. Hence, the EU's legitimacy as a system based on the rule-of-law warrants renewed consideration (Falkner 2013a, 2013b). Relatively bestplaced to judge the situation is without doubt the European Commission who, in its latest annual monitoring report, states that the 'high number of infringement procedures, which in 2016 rose to a five-year peak, remains a serious concern' (European Commission 2017a: 32). ${ }^{3}$ Since failure to comply ultimately deprives citizens and businesses of their benefits under EU law, the Commission 'attaches great importance to ensuring the effective application of the law' (ibid.).

Indeed, Table 1 (below) reveals an impressive amount of relevant Commission activity.

EU action on suspected infringements often starts with the registration of a complaint by individuals. Over time, such a complaint - as well as an own-initiative enquiry by the Commission - may reach the stage of a Letter of Formal Notice which starts the formal part of an infringement proceeding (in very roughly $1 / 4$ of the complaints cases) and later - at rare times - even reach the CJEU (who hands down a judgment in about 1 out of 35 Letters of Formal Notice ${ }^{4}$ ).

The number of open infringement proceedings with the Commission has by the end of 2016 been 'higher than all previous years' (European Commission 2016: 24). By contrast, the cases referred to the CJEU have decreased consistently and significantly from 212 in 2007 to 31 in 2016 (see Table 2 below; compare also Hofmann 2018a, this issue) and so have, consequently, the infringement cases judged: While, during the five year period 2005 to 2009, the annual average was 127 judgments, it was only 67 for 2010 to 2014 and has further shrunk in the two most recent years (European Commission 2015, 2016: 31 judgments each). ${ }^{5}$

The constant decline in new cases brought to Court since 2007 came as a surprise to researchers, for several reasons. The Commission never had a 'mission accomplished' celebration regarding better compliance with EU law. There was - at least, until 2017 (see end of this section) - no official change in the Commission's strategy. ${ }^{6}$ Crucially, the EU saw its membership increased by 10 new countries in 2004, by 2 in 2007 and by one in 2013. Therefore, once all legislation had entered into force in the acceding states, even a constant number of Court referrals would have meant a significant decrease in non-compliance cases by member state. ${ }^{7}$ At the same time, studies in some new 
Table 1. Overview of infringement proceedings status quo (2016).

\begin{tabular}{|c|c|c|c|}
\hline No. & STEP IN (INFORMAL) INFRINGEMENT PROCEEDINGS & PERIOD & REMARKS \\
\hline 3783 & New complaints registered by Commission & In 2016 & \\
\hline 3458 & Complaints handled by Commission (COM) & In 2016 & $\begin{array}{l}\text { Of which } 3026 \text { closed, since: } \\
\text { - no EU law breached ( } 2253) \\
\text { - correspondence does not } \\
\text { qualify as complaint ( } 667) \\
\text { - COM lacks power to act ( } 86) \\
\text { - withdrawal by initiator }(20)\end{array}$ \\
\hline & Investigations under EU Pilot mechanism launched & In 2016 & $\begin{array}{l}\text { Of which } \\
-520 \text { on Commission's own } \\
\text { initiative } \\
-270 \text { triggered by complaints } \\
\text { or inquiries }\end{array}$ \\
\hline 1175 & EU Pilot files open (see below in text for more information) & $\begin{array}{r}\text { By end } \\
2016\end{array}$ & $\begin{array}{l}\text { By contrast, } 875 \text { EU Pilot files } \\
\text { were closed during 2016: } \\
\text { - } 630 \text { with satisfactory answers, } \\
-245 \text { closed because COM } \\
\text { rejected the response. }\end{array}$ \\
\hline \multicolumn{4}{|c|}{ FORMAL PHASE (Article 258 TFEU): } \\
\hline & Letters of Formal Notice & In 2016 & \\
\hline 847 & $\begin{array}{l}\text { Late transposition infringement cases opened (no Reasoned } \\
\text { Opinion needed to sue with CJEU) }\end{array}$ & In 2016 & \\
\hline & Reasoned Opinions & In 2016 & \\
\hline & Referrals to Court of Justice & In 2016 & \\
\hline & CJEU Judgments under 258 TFEU & In 2016 & 23 in favour of COM \\
\hline \multicolumn{4}{|c|}{ '2 $2^{\text {nd }}$ PROCEEDINGS' PHASE (Article 260 TFEU): } \\
\hline & Infringement Proceedings still open after CJEU judgment & $\begin{array}{r}\text { By end } \\
2016\end{array}$ & \\
\hline 3 & Referrals to CJEU for non-compliance with a judgment & $\ln 2016$ & \\
\hline & $\begin{array}{l}\text { Judgments under Article } 260 \text { (2) TFEU for non-compliance with } \\
\text { an judgment }\end{array}$ & In 2016 & 2 with penalty payments \\
\hline & Infringement proceedings still open after $2^{\text {nd }}$ CJEU judgment & $\begin{array}{r}\text { By end } \\
2016\end{array}$ & \\
\hline
\end{tabular}

Source: own compilation from Commission and CJEU annual reports.

Table 2. Infringement proceedings at the CJEU 2005-2016 (Article 258 TFEU).

\begin{tabular}{cccc}
\hline YEAR & NEW CASES & DECLARED INFRINGEMENTS & DISMISSED CASES \\
\hline 2005 & 170 & 131 & 5 \\
2006 & 193 & 103 & 8 \\
2007 & 212 & 127 & 16 \\
2008 & 207 & 94 & 9 \\
2009 & 142 & 133 & 10 \\
2010 & 128 & 83 & 12 \\
2011 & 73 & 72 & 9 \\
2012 & 58 & 47 & 5 \\
2013 & 54 & 40 & 23 \\
2014 & 57 & 41 & 3 \\
2015 & 37 & 26 & 5 \\
2016 & 31 & 27 & 4 \\
\hline
\end{tabular}

Source: CJEU Annual Reports (2005 - 2016), joined cases are counted as one.

member states revealed a 'copy and paste' approach to the transposition of Directives that was followed by frequent problems in applying the relevant EU standards in practice (Falkner, Treib, and Holzleithner 2008 with further references). This suggests a rather increased need for control over compliance, including after formal transposition, for the EU28. 
Four developments come to mind that could possibly explain the puzzle of dwindling Court referrals: first, the Treaty of Lisbon (signed on 13 December 2007, in force since 1 December 2009) provided that the Commission may in case of failure to notify the transposition of a Directive already ask for fines in $1^{\text {st }}$ proceedings before the Court. Such late transposition is a frequent kind of known infringement with 868 open proceedings by the end of 2016 out of 1657 overall (European Commission 2017a: 32). Impending fines may limit the governments' appetite to appear in Court for evident failure to obey the rules. However, it needs mentioning that non-notification is easy to mend but that correct transposition or even application is quite a different challenge. Member states with formerly frequent non-communication of transposition might now at times try to 'window dress' their transposition performance by notifying, without however perfectly complying with the rules at stake. If that happens, the Commission's task to assure good compliance overall, i.e. including after the notification of transposition, would not necessarily shrink much even once dutiful transposition notifications are common.

Second, the decrease in proceedings at the CJEU may result from measures taken to settle implementation problems outside of court. Indeed, the European Commission has set up 'fire-alarm oversight mechanisms by means of transgovernmental networks' (Hobolth and Martinsen 2013: 1406) such as the 'EU Pilot' and 'SOLVIT'. ${ }^{8}$ The latter is an on-line problem solving network confined to Internal Market issues. ${ }^{9}$ Already since 2002, national SOLVIT centres as part of the national administration handle complaints submitted by citizens or businesses via a joint database of cases, so that information is shared efficiently and best practice can spread. In 2008, a website called EU Pilot was set up to improve communication and problem-solving out of court for all realms of EU policy. It has since been used by the Commission before taking the first step of an infringement procedure under Article 258 TFEU. Complaints under this project are examined by the responsible service in the Commission and forwarded to the national authority.

However, the Commission itself acknowledged already in 2012 that the out-of-court problem-solving mechanisms EU Pilot and SOLVIT were all but a panacea and that it would 'use its enforcement powers with the utmost vigour' (European Commission 2012: 7) and requested the cooperation of the member states to ensure that breaches of EU law are swiftly brought to an end. This suggests that the outlined early-stage mechanisms help clear a significant number of problems without however being forceful enough to bring governments in line, should they not be ready or easily capable to cooperate. This is confirmed by latest data (2016): about 245 Pilot files were closed because the Commission rejected the responses provided by the member states (European Commission 2017a: 21) and the resolution rate seems in constant decline. ${ }^{10}$ 233 Pilot files were followed by formal infringement proceedings (more than the year before) and the large majority of these (168) had even been launched on the Commission's own initiative and not by external complainants (ibid.: 21). For these reasons, it seems that the Commission has lost some of its faith in novel ways to easily and quickly fix breaches of EU law informally: It will from now on 'be avoided that the recourse to EU Pilot adds a lengthy step to the infringement process, which is in itself a means to enter into a problem-solving dialogue with a member state' (ibid.: 20).

A third explanation for the lower number of Court referrals could be the Commission's resigning to immutable circumstances (see also Hofmann 2018a, this 
issue). While the armoury against glaring non-compliance has been somewhat strengthened in recurrent Treaty reforms, it seems that many member states continue to disapprove of regular in-depth enquiries in perceived 'internal affairs'. Beyond the superficial control if a member state actually transposes Directives at all, the Commission is short of adequate resources to establish the quality of transposition and application of EU rules. In addition to the general shortage of workforce and the recently even shrinking budget of the Commission, it needs highlighting that governments actually withhold essential tools for efficient and in-depth control: The Commission lost a longstanding struggle over 'correlation tables' that should regularly explain how specific provisions of Directives have been transposed. ${ }^{11}$ In the absence of such instruments, the control of compliance in the EU is a Herculean task - which the Commission quite rationally needs to tailor to its own (and the Court's) capacities. After all, the Commission is free to choose if and when it transfers a case to the CJEU. ${ }^{12}$ As a consequence, however, one must not mechanically infer better compliance if there are less court submissions.

Finally, as will be discussed later with the ' $2^{\text {nd }}$ referrals' at hand (see section 3 ), it also seems a well-pondered policy of prudence to refrain from over-using and hence de-valuating the instrument of court proceedings. That seems an urgent concern at a time of profound rule-of-law challenges in at least two EU member states (Poland, Hungary) and open resistance against some Council votes and related CJEU judgments, such as recently concerning the redistribution of migrants (C-643/15 und C-647/15). Crucially, the EU has no powerful means in its hands since even the 'nuclear' option of activating the procedure of Article 7 TEU with a potential suspension of EU membership rights is vain as soon as two or more governments oppose it. ${ }^{13}$

The puzzle of decreasing Court referrals seems officially solved since the European Commission has published, on 19 January 2017, a Communication on 'EU law: Better results through better application' (2017/C 18/02). In fact, what is called a new strategy may have been applied already during the preceding years, at least with regard to Court referrals, i.e. a 'more strategic approach to enforcement in terms of handling infringements' (ibid.: 11). The Commission will 'distinguish between cases according to the added value which can be achieved by an infringement procedure and will close cases when it considers this to be appropriate from a policy point of view' (ibid.: 15).

Interestingly, the Commission also states that an 'overall decrease of the number of infringement procedures can be put in relation to the important increase of preliminary rulings under Article 267 TFEU since 2010' (European Commission 2015: 16). It informs that the Court of Justice has addressed issues of conformity of national with EU rules 'in about half of its judgments under Article 267 TFEU since 2010 and identified non conformities in numerous cases' (ibid.). It is to be welcomed that the Commission will systematically follow-up on preliminary rulings where the Court identified non-conformities of national legislations (ibid.). At the same time, it needs mentioning that in relative terms the preliminary rulings have declined from 268 new references during the year 2000 for the EU-15 (17,9 per member state) to still only 470 new preliminary references in 2016, which is a record in history in absolute numbers but means only 16,8 per member state. ${ }^{14}$ 
In any case, since preliminary rulings at the CJEU are requested by national courts and not by the European Commission, the latter indeed increasingly relies on lower-level action against non-compliance - which confirms a hypothesis voiced in this Special Issue, i.e. that the Commission is increasingly outsourcing enforcement action (Hofmann 2018a, this issue). In this case, it is externalising not only to private parties (which need to bring domestic Court actions, in the first place) but also to national courts and national authorities, at large (European Commission 2017b: 16). As A. Hofmann argues in this issue, however, such an approach could be dangerous if lower-level authorities do not comply and if those with a valid grievance cannot always (afford to) access a national court (see also Eliantonio 2018 for the specific realm of environmental policy, p. 753-767 in this issue).

To understand the Commission's recent move we should know more about the post-litigation phase. Section 2 will hence discuss the submission of ' 2 nd $p$ proceedings' (i.e. under Article 260.2 TFEU) at the CJEU, a task the Commission cannot possibly outsource.

\section{The amount and upshot of $2^{\text {nd }}$ proceedings}

During the years preceding the 1992 Treaty reform of Maastricht, about four ' 2 nd judgments' were issued every year because a member state had not complied with an CJEU verdict (Kilbey 2010: 371, with further references) but, if such 'shaming' did not work, the EU had no weapon at its disposal to pressurize for obedience (Tallberg 2000). In more recent times, whenever persistent member state non-compliance with CJEU judgments occurs, the Commission 'may bring the case before the Court after giving that State the opportunity to submit its observations. It shall specify the amount of the lump sum or penalty payment to be paid by the member state concerned which it considers appropriate in the circumstances. If the Court finds that the member state concerned has not complied with its judgment it may impose a lump sum or penalty payment on it' (Article 260.2 TFEU).

The Commission used its new enforcement instrument slowly and cautiously. By the end of 2016, only $322^{\text {nd }}$ judgments existed. Since the first $2^{\text {nd }}$ judgment was handed down in 2000, the annual average of judgments under Article 260.2 TFEU is below two $(1,88)$. Over time, the frequency of $2^{\text {nd }}$ proceedings increased, at least until 2013, when the maximum number of five $2^{\text {nd }}$ proceedings ever judged in one year was reached. ${ }^{15}$

Overall, the Commission considers that member states 'frequently take the necessary measures to comply with the judgment of the Court of Justice in a timely manner' (European Commission 2015: 13). Still, a significant number of open proceedings exist both after $1^{\text {st }}$ judgments and after $2^{\text {nd }}$ judgments of the CJEU, as Table 3 reveals below:

Considering that the Commission may choose from about hundred (acknowledged) cases per year, it is interesting to note that it persistently only makes less than a handful of $2^{\text {nd }}$ referrals. That could be a result of successful pre-court settlements ${ }^{16}$ as well as of strategically limiting such highly visible controversies.

A successful deterring effect may indeed result from the Commission and the Court's strategy to make $2^{\text {nd }}$ proceedings successively stricter on the member states. In the early times, CJEU proceedings were withdrawn by the Commission as soon as compliance occurred, even after an Advocate General's statement. ${ }^{17}$ Meanwhile, member states can 
Table 3. Post-CJEU infringement proceedings, official data.

\begin{tabular}{lccc}
\hline By end of & $\begin{array}{c}\text { Open infringement cases where } \\
\text { member states fail to comply after } \\
1^{\text {st }} \text { judgment (Art. 258 TFEU) }\end{array}$ & $\begin{array}{c}2^{\text {nd }} \text { judgments } \\
\text { (during year; } \\
\text { total by end 2016: 32) }\end{array}$ & $\begin{array}{c}\text { Open infringe- } \\
\text { ment cases after } \\
2^{\text {nd }} \text { judgment }\end{array}$ \\
\hline 2011 & 77 & 2 & No data. \\
2012 & 128 & 3 & No data. \\
2013 & 113 & 5 & No data. \\
2014 & 61 & 5 & 7 \\
2015 & 85 & 3 & 7 \\
2016 & 95 & 2 & 10 \\
\hline
\end{tabular}

Source: own compilation from Commission and CJEU annual reports.

be sanctioned for any delay incurred after the Commission's deadline set in the Letter of Formal Notice during $2^{\text {nd }}$ proceedings. ${ }^{18}$ Additionally, both a lump sum and a periodic penalty payment can be imposed since $2005 .^{19}$

With regard to the content of EU policies and their implementation in the member states, the Commission's posture has become stricter, as well. The example of waste management is instructive here: While the Commission 'ceased to demand the penalty payment ordered by the Court in its judgment in Commission vs. Greece (C-387/97...) as soon as the illegal landfill at issue ... had been closed down and replaced with ... an interim solution', the Greek argument 'that the mere adoption of the administrative measures necessary for the cleaning up of illegal landfills should be sufficient ... to avoid a periodic penalty' was not accepted in a later, closely related case (C-378/13, par. $43+36$ of judgment). Nowadays, the Commission requests illegal landfills to be both closed down and cleaned up (see also case C-196/13 against Italy).

However, the Commission's limited resources in following up on infringements ${ }^{20}$ in an enlarged EU, the number of files closed with less than perfect compliance (Falkner 2015), as well as the significant amount of cases open still after $2^{\text {nd }}$ judgment - at times, for many years - may also contribute to the comparatively small numbers of $2^{\text {nd }}$ referrals. Indeed, earlier research (Falkner 2015) suggests that the Commission needs to take great care not to over-use its relatively young resource of penalization for nonobedience to CJEU judgments. Although the Commission is usually exceedingly successful, once it has chosen to sue again (in only four cases out of 32, the CJEU did not impose any kind of fine on the member state), the weapon is, in actual fact, easy to blunt:

First, the case of Greece has shown that even a less wealthy state can afford to keep paying the EU's fines in their present size ${ }^{21}$ and, in a worst case scenario, penalization could therefore become a kind of 'infringement tax' without much deterring effect (see Falkner 2015). Such a development might at some point even backfire on the EU due to citizens' discontent over such a spending of public funds. Second, even impending or imposed penalties do not always make a member state obey (and Table 3, above, suggests that non-compliance even after $2^{\text {nd }}$ judgments is growing; see also section 4 below). At the same time, the Commission always risks losing a member government's benevolence that may, however, seem precious for other purposes: 'putting too much stress on sanctions holds an inherent risk for the essentially cooperative relations between the EU and its member states' (Bieber and Maiani 2014: 1092). Moreover, the 
Commission has in the past even seen harsh counter-action with, at times, pleas that the CJEU later considered 'manifestly lacking any foundation in law'. ${ }^{22}$

The next section (4) will discuss why member states seem to have run the risk of being fined for non-compliance with CJEU judgments.

\section{The main causes of $2^{\text {nd }}$ judgments}

Proceedings with financial fines impending constitute the peak of the above-water tip of the iceberg of non-compliance. Although many compliance studies have chosen statistical approaches and country-level factors, the still limited number of cases in this category allows us to use a 'thick' qualitative approach focused on the individual court proceedings to grasp why (suspected) non-compliance could withstand the increasingly strong enforcement pressures of the EU Commission in these most persevering cases of the EU's litigation history. ${ }^{23} \mathrm{CJEU}$ judgments are a category of text that is well qualified to serve as the basis for social science analysis. The usual material for such enquiry, in particular media reports, falls far short of the outstanding character of judgments, as the following list of criteria indicates:

- CJEU judgments in infringement proceedings are, in principle, ${ }^{24}$ highly elaborate texts. Their content is regulated (CJEU Rules of Procedure, Art. 87) and includes a summary of the facts and the grounds for the decision.

- They are professionally drafted according to complex procedures (CJEU Rules of Procedure, Title II). ${ }^{25}$

- Each CJEU judgment involves a number of top qualified personnel, so there are multiple checks against ad hoc formulations and opinionated statements. The Judges work in chambers of at least three Judges and up to fifteen Judges in the 'Grand Chamber' (CJEU Rules of Procedure, Art. 27). Each case is assigned both a Judge to act as rapporteur and an Advocate General. Each Judge who has taken part in the deliberations needs to sign the original of the judgment, as do the President of the CJEU and the Registrar (ibid.: 88).

- Judges and Advocates General even take an oath to perform their duties impartially and conscientiously (CJEU Rules of Procedure: Art. 4).

- The Court may hear witnesses and experts under oath (ibid., Art. $68+69$ ) and experts' reports may be obtained.

In short, there are good reasons to trust that all parties' views are presented in a more neutral manner than in most alternative sources of potential social science enquiry, and that the member states and their legal representatives do mention if reasons other than advantages for the government or its clientele account for non-compliance. ${ }^{26}$

In methodological terms, it is a challenge that the motives for governmental (non-) action cannot be 'proven' since one will usually not find a 'smoking gun' and nobody will admit advantage-seeking. However, one can establish a) the presence of beneficial effects (financial or other) for governments or their clientele, ${ }^{27}$ and $b$ ) the absence of other convincing justifications for the member state's non-compliance.

In procedural terms, the enquiry into the 32 judgments under Article 260.2 TFEU and the ensuing categorization therefore proceeded with a particular emphasis on the 
member states', as well as the Commission's and the CJEU's arguments contained in the judgments. Where necessary, the qualitative text analyses included also further casespecific documents such as the Commission's action submitted to the Court and the Advocate General's opinion, and even earlier related cases.

Compliance failures may result from either opposition or inability (e.g. Falkner et al. 2005: 13). While 'structural blockage' refers to an unintended impasse due to e.g. decentralised decision-making in a federal state, the label of 'governmental recalcitrance' shall be used here for what seems an explicit or implicit strategy not to adapt to EU standards. The source of the latter may be the wish to circumvent a considerable misfit with domestic policy traditions, to postpone costs for the public coffers, to reap political advantages via protectionism or clientelism, or an issue of interpretation which the member state prefers to be clarified at the CJEU. Specific cases may combine periods of governmental recalcitrance and structural blockage ${ }^{28}$ but it seems nevertheless instructive to categorize the probable 'main causes' for an easier overview and an, at least, basic understanding of the $2^{\text {nd }}$ judgment dramas' underlying rationale.

In fact, 'innocent' examples for $2^{\text {nd }}$ judgments seem rare. The attitude not to obey the Commission's demands regarding compliant behaviour due to diverging views regarding duly legal matters exists. Such plausible issues of interpretation seemed, however, the key cause in (at best) two of the $322^{\text {nd }}$ judgments (both without fines). ${ }^{29}$

Whilst such reasons seem unimpeachable, the member states plead in vain in cases of structural blockage due to sub-state or para-state decision-making, which appeared to be main causes five times among the 32 judgments studied. ${ }^{30}$ In other words, decentralised administrative or judicial discretion, corporatism or federalism are systematically not accepted by the CJEU as a legitimate excuse since EU law would otherwise risk getting incapacitated: 'a member state cannot plead provisions, practices or situations prevailing in its domestic legal order to justify failure to observe obligations arising under EU law' (C-584/14, par. 53; this is a standard formula). However, it needs mentioning that such a defence seems rather more viable in the rare cases when member states were sued rather quickly ${ }^{31}$ than in the many cases showing several decades of noncompliance. In fact, if petty factors like neglect of an inattentive national administration or the latter's comparatively lower 'capacity' (e.g. Börzel, Hofmann, and Panke 2011; Falkner et al. 2005: 335-340) rarely appeared as the principal reason for failures to comply, this is exactly due to the $2^{\text {nd }}$ judgment cases' usually longstanding character that outlasted many short-term blockages caused, for example, by snap elections or national court proceedings.

A few judgments (3) involve cases with important policy misfits where adaptation meant a quite fundamental change, including of principles, that the governments seemingly did not want to impose on their citizens or institutions, ${ }^{32}$ or where they were too late compared to the Commission's sense of urgency in a model case involving the primacy of EU law. ${ }^{33}$

The dominant cluster of 22 cases, however, differs from this group in that no divergent policy approach was presented as a major bone of contention and no opposition in principle made plausible in the case materials. At the same time, advantages occurred for the relevant governments in terms of cost prevention or vote-seeking, ${ }^{34}$ and hence there are indicators suggesting that non-compliance may have been motivated (that fits also the gist of the contribution of Hofmann 2018b, this issue). 
The numbers specified above should be read as indicative because determining 'main causes' to explain an infringement is intrinsically complex and an inter-subjective review might result in slightly different numbers. However, the main finding is an outstanding amount of cases where governments seemingly either under-spent, or over-favoured their clientele, and this promises to withstand any scrutiny. Not only, because cases of other categories than 'governmental recalcitrance' show such signs, in addition. What is more, earlier research has also hinted that 'the case-law illustrates national self-interest at work' (Jack 2013: 405). Finally, the significant reputational and pecuniary costs involved also make plausible that manifest material and political interests seem to matter even more in the $322^{\text {nd }}$ judgments than in less outstanding cases of infringement proceedings and in annulment cases (compare Hartlapp 2018, this issue).

Viewed from the perspective of the policies covered, finally, the study of the 32 judgments under Article 260.2 TFEU is also educative. Environmental policy accounts for 13 cases $(40,6 \%)$, state aid and possible related protectionism (at large) for 9 cases $(28,1 \%) .{ }^{35}$ This confirms that EU environmental policy is generally seen as a highly contested and particularly costly field for the member states (Jack 2013; Hofmann 2018a and Eliantonio 2018 in this issue) - at times more so than expected by the time of adoption. Moreover, environmental policy may require collaboration by large numbers of regional or local actors.

Which lessons can be learned from the ' 2 nd judgments'? Looking at the results in daily life in the relevant member states, the very large majority of such cases seem to have availed advantages to governments. We cannot know if that was a strategic choice but the relevant polity certainly did not do enough to prevent it. Most importantly, it seems that most of these infringements would not have ended or, at least, not at any point soon, without the penalties (see also Jack 2013: 420). Although imposing fines is certainly no panacea (Falkner 2015), they hence seem an indispensable instrument in the EU's arsenal of enforcement measures. By contrast, it seems that a soft 'management approach' to promote compliance, which is based on communication, goodwill, and fear to lose reputation and status (Andersen 2012: 10; Conant 2012: 7-8; Tallberg 2002), will hardly succeed in this top class of infringements.

The first 32 judgments under Article 260.2 TFEU studied for this paper (i.e., all pre2017) suggest $^{36}$ that - quite contrary to the 'new strategy' discussed in section 2 - the Commission and the CJEU should NOT relent their perseverance in enforcing infringements. They could rather increase the fines so that egotistic strategies of governmental cost-cutting or protectionism cannot pay off in financial terms (see also A. Hofmann, p. 785-801 in this issue). Considering that governments think in election cycles, however, speeding up the enforcement of EU law seems most crucial: the naming and shaming as well as the fines' budgetary effects should ideally fall on the very same government that has originally been responsible for implementing an EU rule, not on its successors. Unfortunately, a faster and more systematic control of the implementation of EU law would be demanding for the Commission and the member states - what the governments might not accept.

\section{Conclusions}

One theme of this Special Issue is if interested actors in fact have the capacity to bring their policy conflicts before the CJEU. In the case of the European Commission as the 
official monitor of member state compliance with EU law, that is certainly the case - at least in a formal sense. Considering that its resources are extremely limited if compared to the potentials for non-compliance in a multi-levelled Union of many member states, the Commission needs to make ends meet. It has done so successively (see section 2 above) and recently finally publicized its priorities with a 'more strategic approach to enforcement in terms of handling infringements' (Communication 2017/C 18/02: 11).

This needs to be understood in a wider context. Both institutional resources and prospects of success drive the Commission's enforcement vigour. Lately, various crises have crowded other issues out of busy EU agendas and triggered budgetary cuts while a shadow was cast on the practical success of infringement proceedings. Sections 3 and 4 of this article have revealed that a significant amount of the most persistent infringement cases seems related to various advantages for governments or their clientele, and that even CJEU judgments and $2^{\text {nd }}$ judgments will not always be readily obeyed. The Commission's change in strategy seems to correspond to these developments. Since these matters belong to an area of strict confidentiality, this text has presented indirect evidence and an own analysis of the most persistent infringement cases' backgrounds.

The new strategy of even greater selectivity in going to Court over infringements has significant dangers (as discussed above and by A. Hofmann, p. 785-801 this issue). At the same time, there can hardly be a doubt that it is both legal and understandable: First, the Commission's politics in choosing which cases to pursue, or not, is in full agreement with the Treaties since it 'may' (but it need not) bring cases before the CJEU (Art. 258 and 260.2 TFEU). Second, facing the governments' unwillingness to accept stricter enforcement, the mounting politicization, and lacking resources for ever more proceedings, the Commission's new strategy seems pretty much its only choice.

It stands to reason, however, to expect that if disappointment over incomplete compliance with judgments fed into lesser litigation, lower levels of enforcement could, in turn, produce worse compliance and hence more frustration - as well as worse economic results, since the benefits of a common market can only arise if the rules are applied evenly.

\section{Notes}

1. On decision-making within the Commission, see (Hartlapp 2007; Hartlapp, Metz, and Rauh 2014).

2. For details, see (Andersen 2012; Prete 2017).

3. Thanks for support with data collection and tables to Florian Sowa, Andreas Grantner, Dorothea Tommasi, Veronika Pollak and Maximilian Mansbart.

4. This calculation is indicative only, since all data in Table 1 is for 2016 and the judgments would in fact rather need to be compared to the (various) years of their 'own' Letter of Formal Notice.

5. On the national follow-up to controversial CJEU judgments ( $1^{\text {st }}$ judgments), see (Blauberger 2012).

6. And the Commission was led by José Manuel Barroso throughout 2004 to 2014.

7. 13 new member states to be controlled (in other words, almost double compared to pre2004) would also largely compensate for fewer legislative acts being adopted by the EU. However, note that the legislative acts adopted did not decline steadily each year, as the Court referrals did, but indeed dropped from a high of approx. 220 per year (2008 and 2009) to about 100 per year (2010 and 2011) to rise again to approx. 150 per year (2013 to 2014) and to fall again in 2015 (even below 100); see (Hix, Hageman, and Frantescu 2016: 4). 
Moreover, the drop in Court referrals actually preceded the significant decline in new legislation.

8. For an extended analysis of these mechanisms see (Hobolth and Sindbjerg Martinsen 2013; Smith 2015).

9. See (http://ec.europa.eu/solvit/site/index_en.htm), accessed 13.9.2017.

10. $72 \%$ in 2016 was below the two previous years (European Commission 2017a: 21) and far below the initial success rates of $85 \%(2008-2010)$ and $80 \%(2010-2011)$ as reported by the Commission (Smith 2015: 363).

11. Joint Political Declarations on explanatory documents of 28 September 2011 and 27 October 2011 (2011/C 369/02 and 2011/C 369/03); for details see (Prete 2017: 315f.).

12. On political considerations of the Commission, see (Andersen 2012; Schmidt 2000).

13. And: 'Poland is always backed by the Višegrad group - particularly by Victor Orban's Hungary' (Jacob 2017).

14. All proceedings data stem from the CJEU's annual reports.

15. Considering periods of slightly different length, the average per year has risen from 0,4 (2000-2004) to 1,7 judgments (2005-2010) and even 3,6 annual judgments (2011-2015); see (Falkner 2015).

16. On the Commission's politics of 'friendly settlements', see (Andersen 2012: 17-24) and, very critically, (Smith 2010).

17. E.g., $2^{\text {nd }}$ proceedings regarding Greek non-recognition of foreign higher diploma were closed in 2000 in case C-197/98; related problems seem to have persisted, however (Falkner 2014).

18. See judgment $\mathrm{C}-121 / 07$ of 9 December 2008 against France on genetically modified organisms (par. 60).

19. See judgment C-304/02 of 12 July 2005 against France in the area of protection of fish stock.

20. Melanie Smith also stresses this in her in-depth work regarding the Commission's enforcement policies (2010: 549; 2015: 369).

21. See (Kornezov 2014) on the calculation of the fines.

22. At least two member states have challenged the Commission's calculations of periodic penalties with the EU's General Court. France lost in case T-139/06, Portugal won with case T-33/09 but lost T-810/14, with one plea even 'rejected as manifestly lacking any foundation in law' (par. 78 of judgment). In three cases the Commission so far reimbursed (parts of) the penalties (letter by the Commission's DG Budget, 21 June 2017): In addition to the Portuguese verdict mentioned above, there were two consensual times since Sweden and Spain convinced the Commission out-of-court to pay back (parts of) penalties paid. Italy was bold enough to ask the CJEU for an interpretation of its $2^{\text {nd }}$ judgment (C-496/09 of 17 November 2011) but the latter found that, since 'it is not founded on any difficulty as to the meaning and scope of the judgment which the Court is asked to interpret, the present application must therefore be deemed inadmissible' (judgment C-496/09 INT. of 11 July 2013, par. 12). However, this case of penalty payment was still listed as open by the Commission by mid-2017.

23. What follows are initial findings of ongoing research.

24. There are exceptions of a principled kind (e.g. the orders for closure of a case are usually extremely short) and on a case to case basis (at times, a case may seem so obvious to the responsible judge that the judgment's text may fall short of informing an outsider sufficiently in-depth to grasp the issues at hand). That is, however, hardly ever the case when it comes to the most outstanding of all cases before the CJEU, i.e. particularly the ' 2 nd judgments' for non-compliance of a member state with a $1^{\text {st }}$ judgment.

25. In particular, a preliminary report by the Judge-Rapporteur contains proposals as to whether particular measures should be undertaken (organisation of procedure, measures of inquiry) and as to the formation to which the case should be (CJEU Rules of Procedure, Art. 59).

26. In any case, the procedural alternative to investigate each case in the member state concerned would not only be excessively resource-demanding but also hardly promising: 
If member states do not raise their 'true motives' in Court they will not tell an interviewing researcher, either.

27. This refers to immediate consequences since, in the long run, harmful effects will often result that may be quite costly (consider pollution resulting in poisoning of people and fish) but this is usually beyond the responsible government's tenure.

28. This is a well-known phenomenon in environmental policy cases since governments tend to delay the great investments needed e.g. to safely dispose of dangerous waste. When fines are finally looming, it may be inherently difficult to get a multitude of lower-level actors in line for quick compliance - which would then, however, not be categorized as the 'main cause' of non-compliance here.

29. Case C-503/04 involved a longstanding doctrinal issue about contract rescission when public procurement contracts disregard EU competition law, C-95/12 the famous German Volkswagen law on golden shares in corporate governance.

30. But they showed up as secondary factors in many more cases, particularly those concerned with waste management or recovery of state aid on regional or local levels.

31. See, most importantly, cases C-270/11 and C-243/13 against Sweden.

32. See $\mathrm{C}-177 / 04$ on product liability in France and C-121/07 concerning France and genetically modified organisms.

33. See C-270/11 on data retention in Sweden.

34. Most importantly, granting to their clientele, or citizenship at large, economic advantages vis-à-vis foreign citizens or firms can be expected to help politicians collect votes.

35. 10 cases remain 'miscellaneous'.

36. Others' reform proposals include making the Commission's internal proceedings more transparent (Prete 2017: 355) (Smith 2015) and delegating to the Commissioner whose Directorate General is in charge of the files the adoption of the Letter of Formal Notice since the 'deliberation by the entire College of Commissions of all Letters of Formal Notice (in addition to reasoned opinions and referrals to the Court) seems to demand a very significant, and arguably disproportionate, amount' of time (Prete 2017: 389). This seems a worthwhile reform considering, in addition, that 'majority voting in the College of Commissioners is rare' (Hartlapp, Metz, and Rauh 2014: 295). Peers (2012) opted for more transparency in the Commission's proceedings, for transferring the money from fines to good complier states as gratification, and for having the Commission judge violations lest member states appeal with the CJEU ('default judgment' procedure). Note Prete's (2017: 407) warning that 'infringement proceedings will only continue to fulfil their mission to ensure respect ... if reformed.'

\section{Acknowledgments}

Gratefully acknowledged are helpful comments by Bernard Steunenberg, Miriam Hartlapp, Michael Blauberger, and two anonymous referees.

\section{Disclosure statement}

No potential conflict of interest was reported by the author.

\section{References}

Andersen, Stine. 2012. The Enforcement of EU Law: The Role of the European Commission. Oxford: Oxford University Press.

Bieber, Roland, and Francesco Maiani. 2014. "Enhancing Centralized Enforcement of EU Law: Pandora's Toolbox?" Common Market Law Review 51 (4): 1057-1092. 
Blauberger, Michael. 2012. "With Luxembourg in Mind ... the Remaking of National Policies in the Face of ECJ Jurisprudence." Journal of European Public Policy 19 (1): 109-126. doi:10.1080/ 13501763.2012.632150.

Börzel, Tanja A., Tobias Hofmann, and Diana Panke. 2011. “Caving in or Sitting It Out? Longitudinal Patterns of Non-Compliance in the European Union." Journal of European Public Policy 19 (4): 454-471. doi:10.1080/13501763.2011.607338.

Conant, Lisa. 2012. "Compliance and What EU Member States Make of It." In Compliance and the Enforcement of EU Law, edited by M. Cremona, 1-30. Oxford: Oxford University Press.

Eliantonio, Mariolina. 2018. "The role of NGOs in environmental implementation conflicts: 'stuck in the middle' between infringement proceedings and preliminary rulings?" Journal of European Integration 40 (6): 753-768.

European Commission. 2012. Communication on 'Better Governance of the Single Market', COM (2012) 259 Final. Brussels.

European Commission. 2015. Monitoring the Application of European Union Law, 2014 Annual Report, COM(2015) 133 Final. Brussels.

European Commission. 2016. Monitoring the Application of European Union Law, 2015 Annual Report, COM(2016) 230 Final. Brussels.

European Commission. 2017a. Monitoring the Application of European Union Law, 2016 Annual Report, COM(2017) 370 Final. Brussels.

European Commission. 2017b. Communication on 'EU Law: Better Results through Better Application', 2017/C 18/02. Brussels.

Falkner, Gerda, Oliver Treib, Miriam Hartlapp, and Simone Leiber. 2005. Complying with Europe. EU Harmonisation and Soft Law in the Member States. Cambridge/UK: Cambridge University Press 404.

Falkner, Gerda. 2013a. Is the EU a Non-Compliance Community? Towards "Compliance for Credibility" and EU Action for the Protection of Democracy in Europe, 58. Paris: Les Cahiers européens de Science Po. <http://www.sciencespo.fr/centre-etudes-europeennes/fr/content/previous-years>.

Falkner, Gerda. 2013b. "The JCMS Annual Review Lecture 'Is the European Union Losing Its Credibility?'." Journal of Common Market Studies 51: 13-30. Annual Review. doi:10.1111/jcms.12051.

Falkner, Gerda. 2014. Archive of ECJ Penalization Proceedings Analyses. University of Vienna, Austria: Institute for European Integration Research. http://eif.univie.ac.at/databases.php.

Falkner, Gerda. 2015. "Fines against Member States: An Effective New Tool in EU Enfringement Proceedings?" Comparative European Politics 14 (1): 36-52. doi:10.1057/cep.2015.8.

Falkner, Gerda, Oliver Treib, Elisabeth Holzleithner, Emmanuelle Causse, Petra Furtlehner, Marianne Schulze, and Clemens Wiedermann. 2008. Compliance in the Enlarged European Union: Living Rights or Dead Letters? in cooperation with E. Causse, P. Furtlehner, M. Schulze, C. Wiedermann. Aldershot: Ashgate.

Hartlapp, Miriam. 2007. "On Enforcement, Management and Persuasion: Different Logics of Implementation Policy in the EU and the ILO." Journal of Common Market Studies 45 (3): 653674. doi:10.1111/j.1468-5965.2007.00721.x.

Hartlapp, Miriam, Julia Metz, and Christian Rauh. 2014. Which Policy for Europe? Power and Conflict inside the European Commission. Oxford: Oxford University Press.

Hartlapp, Miriam. 2018. "Why some EU institutions litigate more often than others: exploring opportunity structure and actor motivation in horizontal annulment actions." Journal of European Integration 40 (6): 701-718.

Hix, Simon, Sara Hagemann, and Doru Frantescu. 2016. Would Brexit Matter? the UK's Voting Record in the Council and the European Parliament. Brussels, Belgium: VoteWatch Europe. http://eprints. Ise.ac.uk/66261/.

Hobolth, Mogens, and Dorte Sindbjerg Martinsen. 2013. "Transgovernmental Networks in the European Union: Improving Compliance Effectively?" Journal of European Policy 20 (10): 14061424. doi:10.1080/13501763.2013.800791.

Hofmann, Andreas. 2018a. "Is the Commission levelling the playing field? Rights enforcement in the European Union." Journal of European Integration 40 (6): 737-752. 
Hofmann, Tobias. 2018b. "How long to compliance? Escalating infringement proceedings and the diminishing power of special interests." Journal of European Integration 40 (6): 785-802.

Jack, Brian. 2013. "Article 260 (2)TFEU: An Effective Judicial Procedure for the Enforcement of Judgements?" European Law Journal 19 (3): 404-421. doi:10.1111/eulj.12030.

Jacob, Maxime. 2017. Polish Judges Call for Solution without EU Sanctions. Brussels: euractiv.com (a pan-European media network specialised in EU policies. 22.9.2017. http://www.euractiv.com/ section/justice-home-affairs/news/polish-judges-call-for-solution-without-eu-sanctions/.

Kilbey, lan. 2010. "The Interpretation Of Article 260 Tfeu (Ex228 Ec)." European Law Review 35 (3): 370-86.

Kornezov, Alexander. 2014. "Imposing the Right Amount of Sanctions under Article 260 (2)TFEU: Fairness V. Predictability, or How to Bridge the Gaps." Columbia Journal on European Law 20 ((Online Supplement, no issue no.)): 283-307.

Mathieu, Emmanuelle, Christian Adam, and Miriam Hartlapp. 2018. "From high judges to policy stakeholders: a public policy approach to the CJEU's power" Journal of European Integration 40 (6): 653-666.

Prete, Luca. 2017. Infringement Proceedings in EU Law. Alphen aan den Rijn: Wolters Kluwer.

Peers, Steve. 2012. Sanctions for Infringement of EU Law after the Treaty of Lisbon, European Public Law, 18 (1), 33-64.

Schmidt, Susanne K.. 2000. "Only an Agenda Setter? the European Commission's Power over the Council of Ministers." European Union Politics 1 (1): 37-61. doi:10.1177/1465116500001001003.

Smith, Melanie. 2010. "Inter-Institutional Dialogue and the Establishment of Enforcement Norms: A Decade of Financial Penalties under Article 228 EC (Now Article 260 TFEU)." European Public Law 16 (4): 547-570.

Smith, Melanie. 2015. "The Evolution of Infringement and Sanction Procedures: Of Pilots, Diversions, Collisions, and Circling." In The Oxford Handbook of European Union Law, edited by A. Arnull and D. Chalmers, 350-375. Oxford: Oxford University Press.

Tallberg, Jonas. 2000. "The Anatomy of Autonomy: An Institutional Account of Variation in Supranational Influence." JCMS: Journal of Common Market Studies 38 (5): 843-864. doi:10.1111/ 1468-5965.00267.

Tallberg, Jonas. 2002. "Paths to Compliance: Enforcement, Management, and the European Union." International Organization 56 (3): 609-643. doi:10.1162/002081802760199908.

Toshkov, Dimiter, Moritz Knoll, and Lisa Wewerka. 2010. Connecting the Dots: Case Studies and EU Implementation Research Institute for European Integration Research, Vienna: Working Paper 10/2010. http://eif.univie.ac.at/downloads/workingpapers/wp2010-10.pdf

Voorst, Stijn van. 2017. "Evaluation Capacity in the European Commission." Evaluation 23 (1): 2441. doi:10.1177/1356389016680877.

Voorst, Stijn van, and Ellen Mastenbroek. 2017. "Enforcement Tool or Strategic Instrument? the Initiation of Ex-Post Legislative Evaluations by the European Commission." European Union Politics online first, 7, September. doi:10.1177/1465116517725901http://journals.sagepub.com/ doi/abs/10.1177/1465116517725901 